\title{
49. SECONDARY MINERALS IN SOME BASALTIC ROCKS FROM DEEP SEA DRILLING PROJECT LEGS 52 AND 53, HOLE 418A
}

\author{
C.M. Scarfe, Department of Geology, University of Alberta, Edmonton, Alberta, Canada
}

\section{INTRODUCTION}

There is considerable evidence that the basaltic layer of the oceanic crust has undergone pervasive low temperature $\left(<100^{\circ} \mathrm{C}\right)$ alteration by sea water. Isotopic and mineralogical studies of basalts from DSDP Leg 37, which were drilled near the Mid-Atlantic Ridge at $37^{\circ} \mathrm{N}$, show that young oceanic crust (Hole 332B: 3.5 m.y.) has been altered to at least a depth of 600 meters at temperatures of $\sim 4^{\circ} \mathrm{C}$ (e.g., Muehlenbachs, 1977; Scarfe and Smith, 1977a, b). Moreover, geophysical evidence (e.g., Lister 1972, 1974; Wolery and Sleep, 1976; Anderson et al., 1977; Houtz and Ewing, 1976) suggests that the nature of alteration of the basaltic layer changes with age or distance from the mid-ocean ridge. Sampling of 544 meters of the basaltic layer in DSDP Legs 52 and 53 (Hole 418A: 109 m.y.) at $25^{\circ} \mathrm{N}$ on the Bermuda Rise has provided a unique opportunity to compare alteration in the old oceanic crust with that observed in the young crust in Leg 37, Hole 332B.

The principal minerals associated with low temperature weathering of sea-floor basalts are carbonates, clays, zeolites, and hydrated Fe-oxides. These secondary minerals provide evidence for the mechanism and conditions of basalt-sea water interaction, and they may exert important controls on geochemical budgets and the composition of sea water through time (e.g., Scarfe and Smith, 1977b).

\section{SAMPLE SELECTION AND METHODS OF ANALYSIS}

Samples ( 10 to $50 \mathrm{~g}$ ) were selected by the shipboard parties for their high degree of alteration. The rocks are frequently porphyritic with between 5 to 15 per cent plagioclase, olivine, and minor clinopyroxene phenocrysts. They are basalt flows, pillow breccias, and pillow selvages which have undergone varying degrees of alteration estimated to be between 10 and 100 per cent.

Standard petrographic and X-ray diffraction methods were used for identification purposes. Quantitative chemical analyses were obtained using an ARL EMX microprobe fitted with an Ortec energy-dispersive spectrometer. Methods used for background shaping and scaling, overlap corrections, and adjustment for instrumental drift have been described by Smith (1975), Smith et al. (1975), and Smith and Gold (1976). Normal operating conditions were $15-\mathrm{kV}$ operating voltage, $30-\mathrm{nA}$ probe current, and 400 -s counting times. Special methods were used for analysis of zeolites and some clays. A beam current of $20 \mathrm{nA}$, counting times of $100 \mathrm{~s}$, and a moving-sample technique were used to prevent damage. The limit of detection using the above methods is $\sim 500 \mathrm{ppm}$, and accuracies for major and minor elements are comparable to wavelength dispersive analysis.

\section{RESULTS}

Alteration is present throughout the entire core $(544 \mathrm{~m})$ and the most common secondary minerals are clays and carbonates, conspicuous in veins and vesicles. Olivines are usually altered to clay, although in the lower part of the hole some fresh olivine and basaltic glass survive. Plagioclase is typically unaltered except for the occasional presence of clays along cleavage planes. Fine-grained and quench groundmass clinopyroxene has undergone substantial alter ation to clays, the intensity of alteration correlating closely with proximity to fractures and breccia cavities which acted as conduits for circulating sea water. A summary of secondary minerals found in Hole 418A is given in Table 1.

\section{Glass and Palagonite}

Fragments of fresh glass occur throughout the lower part of the core. The glass is tholeiitic (Table 2) and is close in composition to average Mid-Atlantic Ridge tholeiite (Melson and Thompson, 1971).

Alteration of the glass to palagonite usually proceeds from a fibrous form around cracks and fissures in the glass (Plate 1, Figure 1) to a mottled texture of radiating centers within the glass which finally coalesce to form extensive areas of palagonite (Plate 1, Figure 2). The occasional development of pale brown to pink areas around plagioclase crystals and cracks in some glass (Plate 1, Figure 1) may be associated with the introduction of abundant potassium and the formation of poorly crystalline K-feldspar. The high $\mathrm{K}$-content of these areas is clearly shown in X-ray scanning photographs (Plate 2).

Chemical changes accompanying palagonitization are available, but involve principally the addition of $\mathrm{H}_{2} \mathrm{O}$ and $\mathrm{K}_{2} \mathrm{O}$ and the loss of $\mathrm{CaO}$ and $\mathrm{Na}_{2} \mathrm{O}$ (Table 3). Since there is no evidence for expansion or contraction during palagonitization, these gains and losses are calculated on the assumption that alteration takes place at constant volume (see also Hay and Iijima, 1968; Muehlenbachs and Clayton, 1972).

\section{Carbonates}

Calcite occurs conspicuously in veins and vesicles, but is also present as an alteration product disseminated in the bulk rock. In veins and vesicles calcite follows clay in the paragenesis (Plate 1, Figure 4). Microprobe analyses of calcites show only traces of $\mathrm{MgCO}_{3}, \mathrm{FeCO}_{3}$, and $\mathrm{MnCO}_{3}$.

\section{Clays}

Clays occur in veins, as vesicle linings, and as alteration products of mafic minerals, particularly olivine (Plate 1, Figures 3-6). The clays fall into two broad chemical 
TABLE 1

Summary of Secondary Minerals Identified in Basalts From Hole 418A

\begin{tabular}{|c|c|c|c|c|c|c|c|c|c|c|}
\hline $\begin{array}{c}\text { Sample } \\
\text { (Interval in } \mathrm{cm} \text { ) }\end{array}$ & $\begin{array}{l}\text { Lab. } \\
\text { Number }\end{array}$ & $\begin{array}{l}\text { Sample } \\
\text { Type }\end{array}$ & $\begin{array}{l}\text { Fresh } \\
\text { Glass }\end{array}$ & Palagonite & Carbonates & Clays & Zeolites & Pyrite & $\begin{array}{l}\text { Hydrated } \\
\text { Fe-Oxides }\end{array}$ & K-Feldspar \\
\hline $16-3,56-60$ & 304 & B & & & $\mathrm{X}$ & $\mathrm{X}$ & & & $\mathrm{X}$ & \\
\hline $17-3,78-81$ & 305 & B & & & $\mathrm{X}$ & $\mathrm{X}$ & & & & \\
\hline $19-7,85-90$ & 306 & BPS & & & $\mathrm{X}$ & $\mathrm{X}$ & & & & \\
\hline $27-1,142-147$ & 307 & BPS & & & $\mathrm{X}$ & $\mathrm{X}$ & & & & \\
\hline $31-3,71-76$ & 308 & BB & & & $\mathrm{X}$ & $\mathrm{X}$ & & & & \\
\hline $36-2,120-122$ & 315 & PB & & & $\mathrm{X}$ & $\mathrm{X}$ & & & $\mathrm{X}$ & \\
\hline $37-1,87-89$ & 309 & B & & & $\mathrm{X}$ & $\mathrm{X}$ & & & $\mathrm{X}$ & \\
\hline $38-1,2-4$ & 317 & BB & & & $\mathrm{X}$ & $\mathrm{X}$ & $\mathrm{X}$ & & & \\
\hline $38-1,18-20$ & 316 & BB & & & $\mathrm{X}$ & $\mathrm{X}$ & & & & \\
\hline $38-4,128-132$ & 310 & PB & & & $\mathrm{X}$ & $\mathrm{X}$ & $\mathrm{X}$ & & & \\
\hline $38-6,58-62$ & 311 & PB & & & $\mathrm{X}$ & $\mathrm{X}$ & & & & \\
\hline $41-4,148-150$ & 312 & $\mathrm{BB}$ & & & $\mathrm{X}$ & $\mathrm{X}$ & & & & \\
\hline $43-2,148-150$ & 313 & B & & & $\mathrm{X}$ & $\mathrm{X}$ & & & & \\
\hline $44-3,22-24$ & 314 & PS & & & & $\mathrm{X}$ & & & $\mathrm{X}$ & \\
\hline $50-1,10$ & 255 & B & & $\mathrm{X}$ & $\mathrm{X}$ & $\mathrm{X}$ & & & & \\
\hline $50-2,102$ & 256 & PS & $\mathrm{X}$ & $\mathrm{X}$ & & & & & & \\
\hline $51-4,34$ & 257 & BPS & & & $\mathrm{X}$ & $\mathrm{X}$ & & & & \\
\hline $52-6,12-14$ & 258 & PS & $\mathrm{X}$ & $\mathrm{X}$ & & $\mathrm{X}$ & & & & \\
\hline $55-2,48-50$ & 259 & B & & & $\mathrm{X}$ & $\mathrm{X}$ & & $\mathrm{X}$ & & \\
\hline $56-6,82-85$ & 260 & PS & $\mathrm{X}$ & & & & & & & \\
\hline $60-5,41-44$ & 261 & B & & & $\mathrm{X}$ & & & & & \\
\hline $65-1,108-110$ & 262 & PBPS & & $\mathrm{X}$ & & $\mathrm{X}$ & & & & \\
\hline $65-4,3-6$ & 263 & PPS & & $\mathrm{X}$ & & $\mathrm{X}$ & & & $\mathrm{X}$ & \\
\hline $68-3,40-42$ & 264 & PS & $\mathrm{X}$ & $\mathrm{X}$ & & $\mathrm{X}$ & & & & \\
\hline $72-4,13-15$ & 265 & PS & & $\mathrm{X}$ & & $\mathrm{X}$ & $\mathrm{X}$ & $\mathrm{X}$ & & \\
\hline $73-2,89-91$ & 266 & PS & $\mathrm{X}$ & $\mathrm{X}$ & & $\mathrm{X}$ & & & & $\mathrm{X}$ \\
\hline $74-5,63-66$ & 267 & PPS & $\mathrm{X}$ & & & & & & & \\
\hline $75-3,120-123$ & 268 & PS & $\mathrm{X}$ & $\mathrm{X}$ & & $\mathrm{X}$ & & & & $\mathrm{X}$ \\
\hline $86-1,82-85$ & 269 & BB & & & $\mathrm{X}$ & $\mathrm{X}$ & & & & \\
\hline $86-2,109-113$ & 270 & PB & & $\mathrm{X}$ & $\mathrm{X}$ & $\mathrm{X}$ & & & & \\
\hline
\end{tabular}

Note: $\mathrm{B}=$ basalt $; \mathrm{BB}=$ basaltic breccia $; \mathrm{PS}=$ pillow selvage $\mathrm{P}=$ abundant phenocrysts.

TABLE 2

Hole 418A: Representative Microprobe Analy ses of Glass and Palagonite

\begin{tabular}{|c|c|c|c|c|}
\hline Lab No. & $266 \mathrm{~A}$ & $268 \mathrm{~A}$ & $266 \mathrm{C}$ & $268 \mathrm{~F}$ \\
\hline $\mathrm{SiO}_{2}$ & 50.3 & 50.4 & 47.8 & 46.9 \\
\hline $\mathrm{TiO}_{2}$ & 1.7 & 1.7 & 2.1 & 2.5 \\
\hline $\mathrm{Al}_{2} \mathrm{O}_{3}$ & 13.9 & 14.0 & 13.0 & 12.1 \\
\hline $\mathrm{Fe}_{2} \mathrm{O}_{3}$ & 12.3 & 11.9 & 17.2 & 13.1 \\
\hline $\mathrm{MnO}$ & 0.2 & 0.2 & - & - \\
\hline $\mathrm{MgO}$ & 7.0 & 7.1 & 8.6 & 5.6 \\
\hline $\mathrm{CaO}$ & 11.5 & 11.5 & 2.1 & 4.7 \\
\hline $\mathrm{Na}_{2} \mathrm{O}$ & 2.5 & 2.6 & 0.3 & 1.3 \\
\hline $\mathrm{K}_{2} \mathrm{O}$ & 0.1 & 0.1 & 1.2 & 0.5 \\
\hline
\end{tabular}

Note: $266 \mathrm{~A}$ and $266 \mathrm{C}$ from Sample $73-2$, $89-91 \mathrm{~cm} ; 268 \mathrm{~A}$ and $268 \mathrm{C}$ from Sample $75-3,120-123 \mathrm{~cm}$; and $\mathrm{A}=$ glass; $\mathrm{C}$ and $\mathrm{F}=$ palagonite. Total iron calculated as $\mathrm{Fe}_{2} \mathrm{O}_{3}$.
TABLE 3

Hole 418A: Representative

Microprobe Analyses of Clays

\begin{tabular}{lrr}
\hline Lab. No. & $259 \mathrm{H}$ & $262 \mathrm{D}$ \\
\hline $\mathrm{SiO}_{2}$ & 51.1 & 43.9 \\
$\mathrm{Al}_{2} \mathrm{O}_{3}$ & 1.8 & 3.2 \\
$\mathrm{Fe}_{2} \mathrm{O}_{3}$ & 27.3 & 15.6 \\
$\mathrm{MgO}$ & 5.3 & 18.5 \\
$\mathrm{CaO}$ & 2.1 & 1.7 \\
$\mathrm{Na}_{2} \mathrm{O}$ & - & 2.9 \\
$\mathrm{~K}_{2} \mathrm{O}$ & 7.3 & - \\
\hline
\end{tabular}

Note: $259 \mathrm{H}=$ green $\mathrm{Fe}-\mathrm{K}$ rich clay from vesicle in Sample 55-2, 48-50 $\mathrm{cm} ; 262 \mathrm{D}=$ brown $\mathrm{Fe}$ $\mathrm{Mg}$-rich clay from vesicle in Sample 65-1, $108-110 \mathrm{~cm}$. Total iron calculated as $\mathrm{Fe}_{2} \mathrm{O}_{3}$. categories: Fe-Mg-rich clays which vary in color from green to brown, and Fe-K-rich clays which are usually a bright green. The Fe-Mg clays are smectites, probably Fe-rich saponites, the color change from green to brown (Plate 1, Figure 6) possibly being associated with the redox state of the iron. The Fe-K-rich clays are tentatively identified as celadonite, although they do not always show characteristic
XRD patterns. The Fe-K-rich clays frequently occur later in the sequence along with calcite in veins and vesicles (Plate 1, Figure 4).

\section{Zeolites}

The only zeolite positively identified from a combination of X-ray and microprobe methods was analcite (Table 4). It 


\begin{tabular}{|c|c|}
\hline \multicolumn{2}{|c|}{$\begin{array}{l}\text { TABLE } 4 \\
\text { Hole 418A: } \\
\text { Representative } \\
\text { Microprobe } \\
\text { Analysis of } \\
\text { Analcite }\end{array}$} \\
\hline Lab. No. & $310 \mathrm{~A}$ \\
\hline $\mathrm{SiO}_{2}$ & 56.2 \\
\hline $\mathrm{Al}_{2} \mathrm{O}_{3}$ & 22.8 \\
\hline $\mathrm{Na}_{2} \mathrm{O}$ & 13.6 \\
\hline $\mathrm{K}_{2} \mathrm{O}$ & 0.1 \\
\hline \multicolumn{2}{|c|}{$\begin{array}{l}\text { Note: } 310 \mathrm{~A}=\text { anal } \\
\text { cite in vein in } \\
\text { Sample } 38-4 \\
128-132 \mathrm{~cm} .\end{array}$} \\
\hline
\end{tabular}

occurs in veins or cavities as white to colorless blocky crystals up to $1 \mathrm{~mm}$ across.

\section{Isotopic Composition of Carbonates and Clays}

Oxygen isotope data on disseminated and vein calcite give $\delta^{18} \mathrm{O}$ values between +24.9 and $+28.5 \%$ (Table 5). These values, along with +17.1 and $+18.1 \%$ for disseminated clay and vein celadonite, are consistent with low temperature alteration by circulating sea water. The calcites yield formation temperatures between $20^{\circ}$ and $41^{\circ} \mathrm{C}$ and a thermal gradient in the oceanic crust of 4 to $7^{\circ} \mathrm{C} / 100$ meters.

The $\delta^{13} \mathrm{C}$ values for calcite (Table 5) are normal for marine carbonates, although Muehlenbachs (this volume) has found exceptionally negative $\delta^{13} \mathrm{C}$ values which may indicate local carbonate precipitation from stagnant pore waters (Anderson et al., 1976).

\section{DISCUSSION}

The mineralogy and isotopic evidence presented above indicates that the basaltic sea floor sampled in Hole 418A has undergone pervasive low temperature alteration. Clays, calcite, analcite, and other secondary minerals were formed

TABLE 5

Hole 418A: Isotopic Composition of Carbonates and Clays

\begin{tabular}{lccc}
\hline $\begin{array}{c}\text { Sample } \\
\text { (Interval in cm) }\end{array}$ & $\begin{array}{c}\delta^{13} \mathrm{C} \\
(\mathrm{PDB})\end{array}$ & $\begin{array}{c}{ }^{18} \mathrm{O} \\
(\mathrm{SMOW})\end{array}$ & $\begin{array}{c}\mathrm{Temp} \\
\left({ }^{\circ} \mathrm{C}\right)^{\mathrm{a}}\end{array}$ \\
\hline Carbonates & & & \\
$19-7,85-90$ vein & +1.8 & +28.5 & 20.0 \\
$51-4,34$ & -2.7 & +24.9 & 40.5 \\
$60-5,41-44$ & -0.2 & +27.5 & 27.1 \\
$86-1,82-85$ & -0.9 & +26.6 & 37.4 \\
& & & \\
Clays & & & \\
$19-7,85-90$ vein & & +18.1 & \\
$55-2,48-50$ & & +17.1 & \\
\hline
\end{tabular}

Note: Analyses of disseminated carbonates and clays except where indicated. Analyst: K. Muehlenbachs.

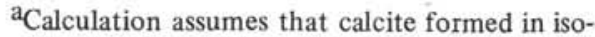
topic equilibrium with normal sea water (O’Neil et al., 1969). by the interaction between basalt and circulating sea water. No evidence has been found for high temperature $\left(>100^{\circ} \mathrm{C}\right)$ hydrothermal alteration.

Although alteration occurs throughout the entire core, it is more pronounced in the top half where fresh glass and unaltered olivine are seldom found. However, fracture zones and breccia horizons at several levels throughout the section provide conduit systems of high permeability (Johnson, this volume) along which alteration is spectacularly developed. In contrast, such downhole variability was not observed in the young crust in Hole 332B.

The dominant clay/calcite paragenesis found in veins and vesicles, together with the poor development of zeolites, has been documented elsewhere in the old crust (e.g., Scarfe and Muehlenbachs, 1977). This association suggests that the alteration may have taken place under conditions of high $\mathrm{CO}_{2}$ activity. Such conditions would suppress zeolite development in favor of the carbonate-bearing assemblage as discussed by Bass et al. (1973) and Scheidegger and Stakes (1977). This effect was coupled with potassium enrichment in clays and palagonite and the development of small amounts of K-feldspar. Similar K enrichment was observed in Hole $332 \mathrm{~B}$ in the young crust, although there the principal $\mathrm{K}$-bearing phases were clay, palagonite, and phillipsite. However, the occasional occurrence of pyrite with the clay carbonate assemblage and the appearance of late-stage hydrated Fe-oxides indicate that the conditions of alteration must have fluctuated considerably during the complete alteration cycle in Hole 418A.

Although temperatures of alteration between $20^{\circ}$ and $41^{\circ} \mathrm{C}$ were calculated from the oxygen isotope data, recently Hart and Staudigel (1978) using strontium isotope methods have shown that vein calcites and clays from Hole 418A formed shortly after the crust was formed, perhaps within the first 10 m.y. Since the alteration of the upper part of young crust takes place at temperatures of about $4^{\circ} \mathrm{C}$, it is evident that calcites and possibly other secondary minerals in Hole $418 \mathrm{~A}$ have re-equilibrated with sea water or trapped pore fluids at temperatures governed by the local geothermal gradient.

Thus it seems that early low temperature alteration of the sea floor is followed by a slow process of re-equilibration at slightly warmer temperatures. After the early stage, massive circulation of sea water ceases except along localized breccia zones which continue to act as conduits in the mature crust.

\section{ACKNOWLEDGMENTS}

S. Cake, S. Launspach, and D.A. Tomlinson are thanked for assistance. P.T. Robinson and M.H. Salisbury supplied the samples and K. Muehlenbachs and R.L. Houghton reviewed the manuscript. Financial support was provided by NRC Grants A8394 and G0082. This report was completed while the author was on sabbatical leave at the University of Sheffield, England.

\section{REFERENCES}

Anderson, R.N., Langseth, M.G., and Sclater, J.G., 1977. The mechanisms of heat transfer through the floor of the Indian Ocean, J. Geophys. Res., v. 82, p. 3391-3409.

Anderson, T.F., Donnelly, T.W., Drever, J.I., Eslinger, E., Gieskes, J.M., Kastner, M., Lawrence, J.R., and Perry, E.A., 1976. Geochemistry and diagenesis of deep-sea sediments from Leg 35 of the Deep Sea Drilling Project, Nature, v. 261, p. 474-476. 
Bass, M.N., Moberly, R., Rhodes, J.M., Shih, C.S., and Church, S.E., 1973. Volcanic rocks cored in the central Pacific, Leg 17, Deep Sea Drilling Project. In Winterer, E.L., Ewing, J.I., et al., Initial Reports of the Deep Sea Drilling Project, v. 17: Washington (U.S. Government Printing Office), p. 429-503.

Hart, S.R. and Staudigel, H., 1978. Ocean crust-seawater interaction: Leg 53, EOS Trans. Am. Geophys. Union, v. 59, p. 409.

Hay, R.L. and Iijima, A., 1968. Petrology of palagonite tuffs of Koko Craters, Oahu, Hawaii, Contrib. Mineral. Petrol., v. 17, p. 141-154.

Houtz, R. and Ewing, J., 1976. Upper crustal structure as a function of plate age, J. Geophys. Res., v. 81, p. 2440-2498.

Lister, C.R.B., 1972. On the thermal balance of a mid-ocean ridge, Geophys. J. Roy. Astron. Soc., v. 26, p. 515-535.

, 1974. On the penetration of water into hot rock, Geophys. J. Roy. Astron. Soc., v. 39, p. 465-509.

Melson, W.G. and Thompson, G., 1971. Petrology of a transform fault zone and adjacent ridge segments, Phil. Trans. Roy. Soc. London, v. 268, p. 423-441.

Muehlenbachs, K., 1977. Oxygen isotope geochemistry of rocks from DSDP Leg 37, Canadian J. Earth Sci., v. 14, p. 771-776.

Muehlenbachs, K. and Clayton, R.N., 1972. Oxygen isotope studies of fresh and weathered submarine basalts, Canadian J. Earth Sci., v. 9, p. 172-184.

O'Neil, J.R., Clayton, R.N., and Mayeda, T.K., 1969. Oxygen isotope fractionation in divalent metal carbonates, J. Chem. Phys., v. 51, p. 5547-5558.

Scarfe, C.M. and Muehlenbachs, K., 1977. Low temperature alteration of old oceanic crust: secondary minerals from DSDP
Legs 11, 26, and 27, EOS Trans. Am. Geophys. Union, v. 58, p. 1174 .

Scarfe, C.M. and Smith, D.G.W., 1977a. Mineralogy and chemistry of secondary phases in some basaltic rocks from DSDP Leg 37. In Aumento, F., Melson, W.G., et al., Initial Reports of the Deep Sea Drilling Project, v. 37: Washington (U.S. Government Printing Office), p. 825-831.

, 1977b. Secondary minerals in some basaltic rocks from DSDP Leg 37, Canadian J. Earth Sci., v. 14, p. 903-910.

Scheidegger, K.F. and Stakes, D.S., 1977. Mineralogy, chemistry and crystallisation sequence of clay minerals in altered tholeiitic basalts from the Peru Trench, Earth Planet. Sci. Lett., v. 36, p. 413-422.

Smith, D.G.W., 1975. An approach to fully quantitative energy dispersive electron microprobe analysis, Ann. Conf. Microbeam Analysis Society, Tenth Proc., Las Vegas, p. 21A$21 \mathrm{D}$.

Smith, D.G.W. and Gold, C.M., 1976. A scheme for fully quantitative energy dispersive microprobe analysis. In Gould, R.W., Barrett, C.S., Newkirk, J.B., and Ruud, C.O. (Eds.). Advances in X-Ray Analysis, Dubuque, Iowa, (Kendall/Hunt Publishing Company), v. 19, p. 191-201.

Smith, D.G.W., Gold, C.M., and Tomlinson, D.A., 1975. The atomic number dependence of the $\mathrm{x}$-ray continuum intensity and the practical calculation of background in energy dispersive electron microprobe analysis, X-ray Spectrom., v. 4, p. 149-156.

Wolery, T.J. and Sleep, N.H., 1976. Hydrothermal circulation and geochemical flux at mid-ocean ridges, J. Geol., v. 84, p. $249-275$. 



\section{PLATE 1}

Hole 418A: Photomicrographs of Glass and Secondary Minerals

Figure 1 Fresh glass containing palagonite along cracks and areas of high $\mathrm{K}$ content surrounding plagioclase crystals (Sample 73-2, 89-91 cm; Lab \#266B). PPL, field $\sim 3 \mathrm{~mm}$ across.

Figure 2 Mottled texture of palagonite alteration in fresh glass (Sample 50-2, $102 \mathrm{~cm}$; Lab \#256). PPL, field $\sim 3$ $\mathrm{mm}$ across.

Figure 3 Olivine altered to green smectite (Sample 38-4, $128-132 \mathrm{~cm}$; Lab \#310A). PPL, field $\sim 2 \mathrm{~mm}$ across.

Figure $4 \quad$ Vein filled with green celadonite followed by calcite (Sample 38-4, 128-132 cm; Lab \#310B). PPL, field $\sim 3 \mathrm{~mm}$ across.

Figure $5 \quad$ Vesicle filled with celadonite followed by pale brown fibrous smectite (Sample 37-1, 87-89 cm; Lab \#309A). PPL, field $\sim 0.5 \mathrm{~mm}$ across.

Figure $6 \quad$ Vesicle filled with green smectite followed by fibrous brown smectite (Sample 65-1, 108-110 cm; Lab \#262C). PPL, field $\sim 0.5 \mathrm{~mm}$ across. 
PLATE 1

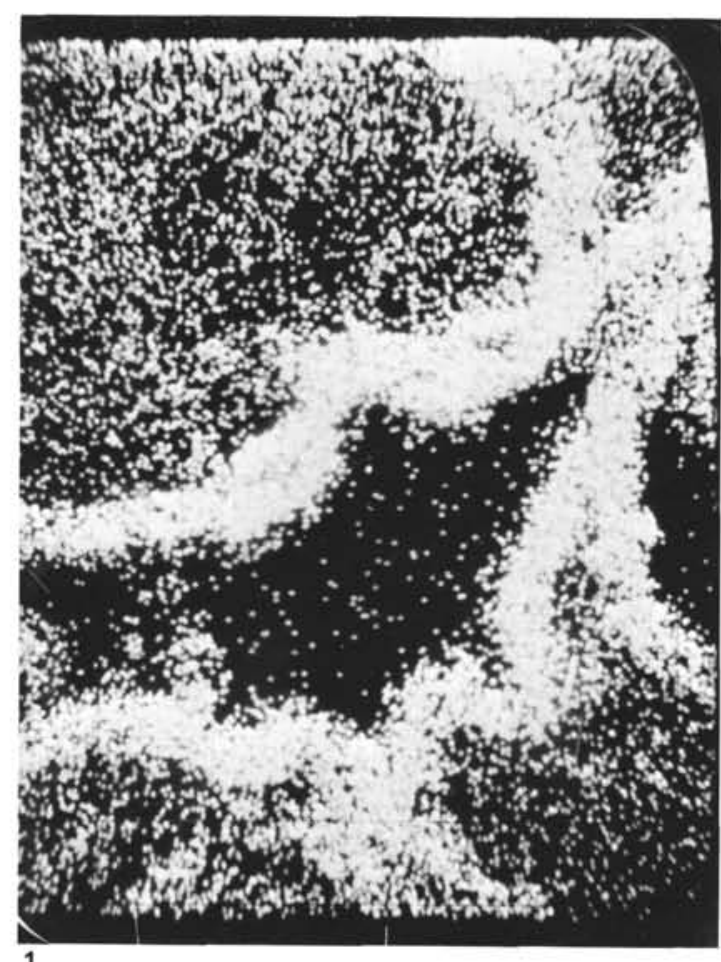

1

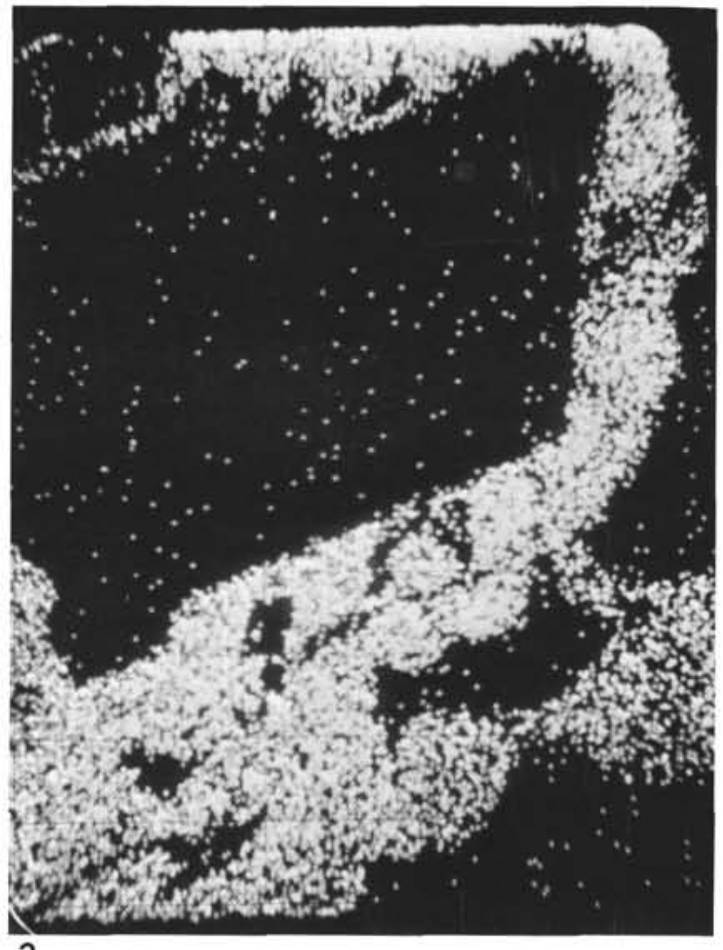

2

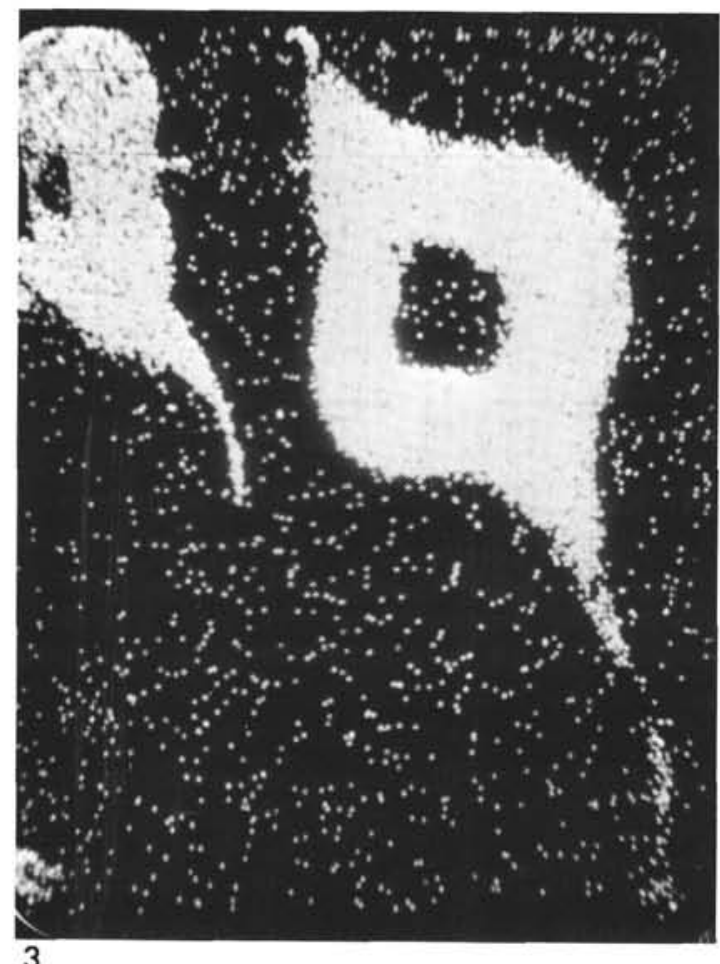

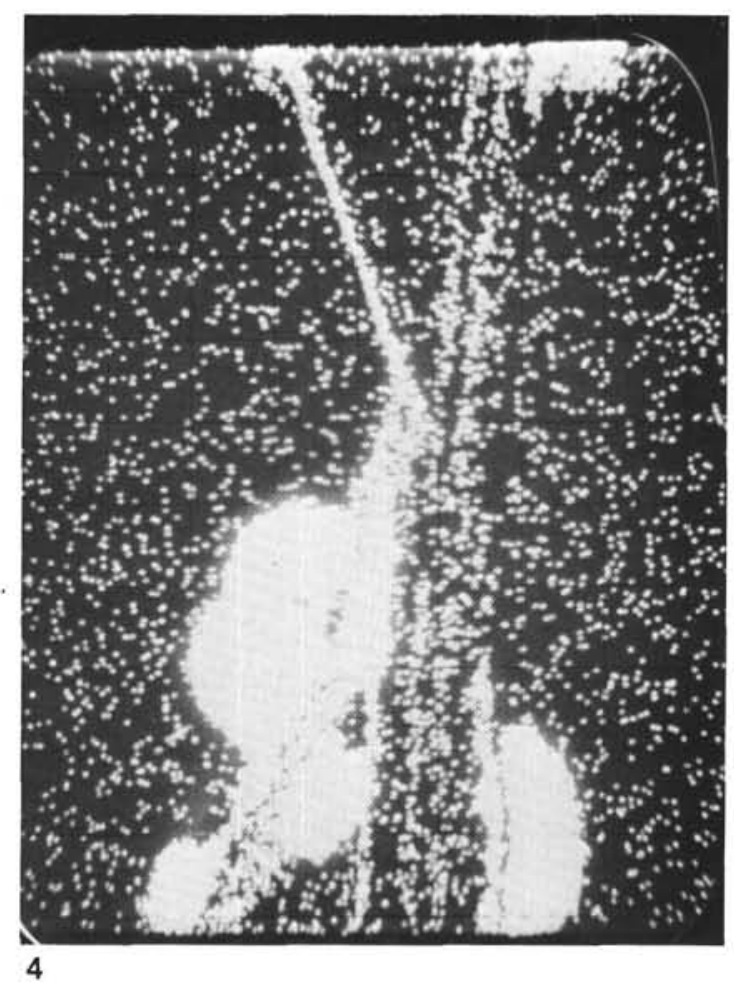




\section{PLATE 2}

Hole 418A: X-Ray Scanning Photographs for K in Glass and Secondary Minerals

Figure 1 Sample 37-1, 87-89 cm (Lab \#309A). Selected from area similar to Plate 1, Figure 5.

Figure 2 Sample 75-3, 120-123 cm (Lab \#268G). Selected from area similar to Plate 1, Figure 1.

Figure 3 Sample 73-2, 89-91 cm (Lab \#266B). Area selected from Plate 1, Figure 1.

Figure 4 Sample 75-3, 120-123 cm (Lab \#268E). Selected from area similar to Plate 1, Figure 1. (For all figures $15-\mathrm{kV}$ operating voltage; $20 \mathrm{nA}$ probe current; 20,000 counts; grid size $48.5 \mu \mathrm{m}$.) 
PLATE 2
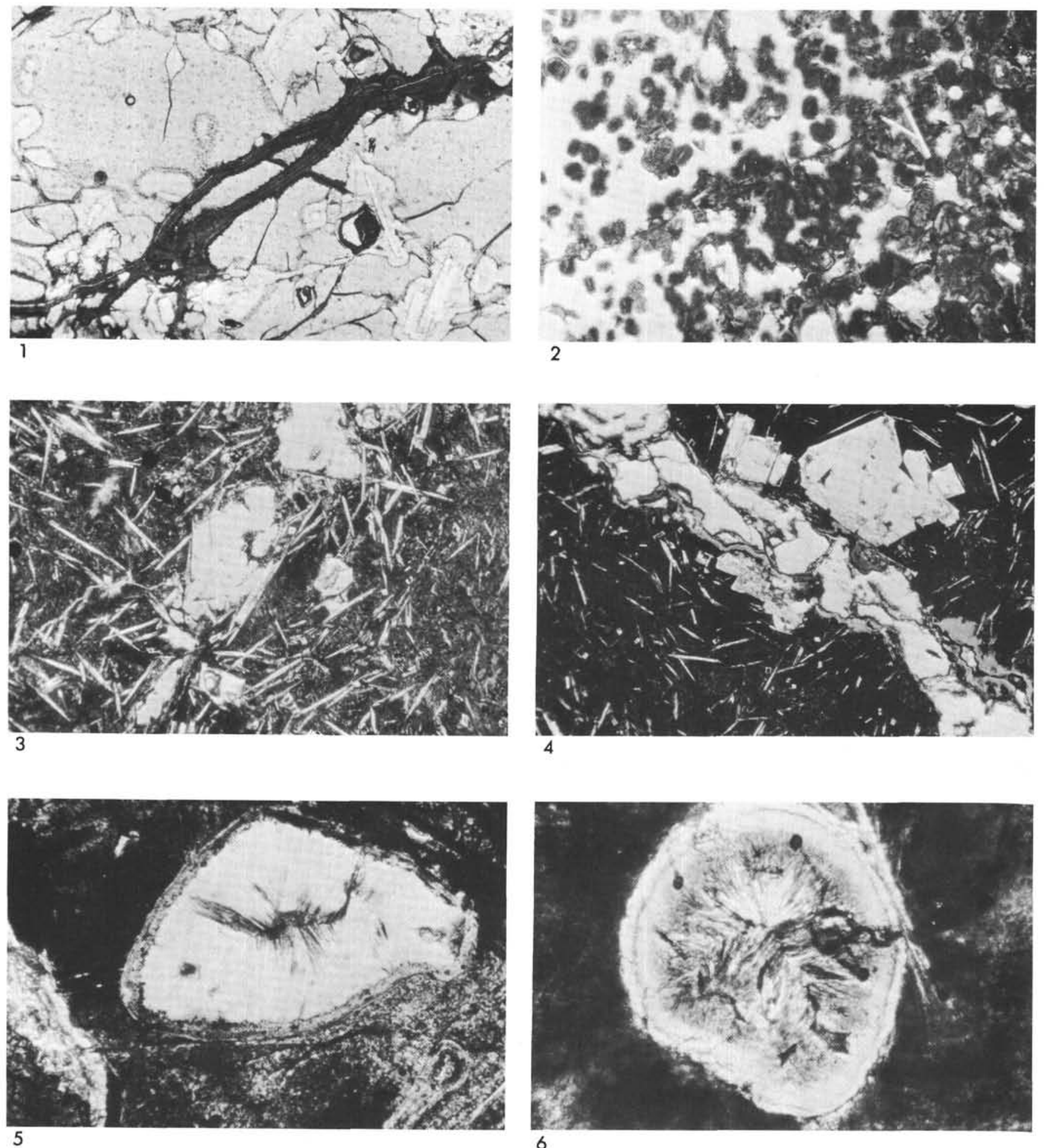